\title{
Clinical effectiveness and safety of montelukast in asthma. What are the conclusions from clinical trials and meta-analyses?
}

This article was published in the following Dove Press journal:

Drug Design, Development and Therapy

26 June 2014

Number of times this article has been viewed

\author{
Kam Lun Ellis Hon' \\ Ting Fan Leung' \\ Alexander KC Leung ${ }^{2}$ \\ 'Department of Paediatrics, \\ The Chinese University of Hong \\ Kong, Prince of Wales Hospital, \\ Shatin, Hong Kong; ${ }^{2}$ Department \\ of Pediatrics, The University \\ of Calgary, Calgary, AB, Canada
}

Correspondence: Kam Lun Ellis Hon Department of Paediatrics, The Chinese University of Hong Kong, 6/F, Clinical Sciences Building, Prince of Wales Hospital, Shatin, Hong Kong

Tel +852 26322859

Fax +85226360020

Email ehon@cuhk.edu.hk

\begin{abstract}
Asthma is a common childhood atopic disease associated with chronicity and impaired quality of life. As there is no cure for this disease, treatment relies on avoidance of triggers such as food and aeroallergens, the use of inhaled bronchodilators/corticosteroids and antiallergic or immunomodulating therapies. Inhaled corticosteroids (ICSs) and bronchodilators have been the mainstay. However, in Asia, myths and fallacies regarding Western medicine and corticosteroids are prevalent and lead to nonadherence to treatment. Also, use of traditional and proprietary herbal medicines is popular. In the past decades, a novel class of nonsteroidal immunomodulating montelukasts has become available. This article reviews the evidence for the effectiveness and clinical efficacy of these medications. A number of randomized and controlled trials have been performed over the years. The majority of studies confirm the usefulness of montelukast as monotherapy and add-on therapy to ICS in mild to moderate childhood asthma across all age groups. ICSs are generally superior to montelukasts for asthma management. However, montelukast has a place in the treatment of young children with viral-triggered wheezing diseases, exercise-induced asthma, and in children whose parents are steroid-phobic and find ICS unacceptable.
\end{abstract}

Keywords: cysteinyl leukotriene receptor antagonist, inhaled corticosteroid, randomized control trial, meta analysis

\section{Introduction}

Asthma is a common, complicated chronic disorder of the airways and is characterized by variable and recurring symptoms, airflow obstruction, bronchial hyperresponsiveness, and underlying inflammation. The Canadian Asthma Consensus guidelines suggest that asthma should be considered in individuals who present clinically with recurrent symptoms of breathlessness, chest tightness, wheezing or cough, and signs of variable airflow obstruction. ${ }^{1}$ Although manifested in the airways, the disease is part of a systemic disease of atopy. ${ }^{2}$

The prevalence of asthma has increased two to three fold over the past three decades in industrialized countries, and there is evidence to suggest that this prevalence continues to increase. ${ }^{3}$ Asthma affects $9 \%$ to $20 \%$ of children and $1 \%$ to $3 \%$ of adults in the United States and is more prevalent in children who belong to upper socioeconomic classes, smaller family sizes, and families with overzealous hygiene. ${ }^{4-10}$ In the People's Republic of China, the prevalence is estimated to be approximately $5 \% .^{11,12}$ The increase in prevalence may be due to increased access to medical care, improved recognition, better epidemiological reporting, or increased environmental allergens due to industrialization and pollution. Conversely, the hygiene hypothesis postulates that the cause of asthma and allergic diseases is an unusually clean environment. The hypothesis states that exposure 
to bacteria and other immune system modulators is important during development, and missing out on this exposure increases risk for allergy. ${ }^{13,14}$ The management of asthma may be suboptimal in Asia because myths and fallacies regarding Western medicine and corticosteroids are prevalent and lead to nonadherence of treatment. ${ }^{15-19}$ Also, use of traditional and proprietary herbal medicines for atopic diseases is popular. ${ }^{20,21}$ Noncorticosteroid-based medications such as montelukast may play a role in better control for various atopic diseases in some of these cities. ${ }^{22,23}$

\section{Pathophysiology of airway inflammation}

Airway inflammation contributes to airway hyperresponsiveness, airflow limitation, respiratory symptoms, and disease chronicity and plays an essential role in the pathophysiology of asthma. Airway inflammation involves an interaction of many cell types and multiple mediators with the airways that eventually results in the characteristic pathophysiological features of the disease. These cells include eosinophils, ${ }^{24-26}$ mast cells, ${ }^{27}$ neutrophils, ${ }^{28-31}$ macrophages, ${ }^{32}$ T lymphocytes, dendritic cells, ${ }^{33}$ and airway epithelial cells. ${ }^{34}$

Subpopulations of lymphocytes, $\mathrm{T}$ helper 1 cells and $\mathrm{T}$ helper 2 cells (Th2), have distinct inflammatory mediator profiles and effects on airway function. Generation of Th2 cytokines (eg, interleukin [IL]-4, IL-5, and IL-13) accounts for the overproduction of immunoglobulin $\mathrm{E}$ (IgE), presence of eosinophils, and development of airway hyperresponsiveness. ${ }^{35}$ There is also a reduction in regulatory $\mathrm{T}$ lymphocytes that normally inhibit Th2 cells as well as an increase in natural killer cells that release large amounts of T helper 1 and Th2 cytokines. ${ }^{36-40}$ Activation of mucosal mast cells releases bronchoconstrictor mediators (histamine, cysteinyl leukotrienes, prostaglandin D2). ${ }^{41-43}$ Cysteinyl leukotrienes are potent bronchoconstrictors derived mainly from mast cells. ${ }^{44-50}$

$\mathrm{IgE}$ is the antibody responsible for activation of allergic reactions and is important to the pathogenesis of allergic diseases and the development and persistence of inflammation. The mast cell has large numbers of IgE receptors that release a wide variety of mediators to initiate acute bronchospasm and proinflammatory cytokines to perpetuate underlying airway inflammation when activated. ${ }^{41,51-53}$

\section{Implications of inflammation for therapy}

The increased understanding of the inflammatory processes in asthma involving cellular and humoral responses and cysteinyl leukotrienes has been translated into therapies targeted at interrupting processes mediated by the aforementioned inflammatory cells and mediators. ${ }^{38}$ Some investigations have yielded promising results, such as the development of leukotriene modifiers and anti-IgE monoclonal antibody therapy.

Therapeutic agents target multiple factors regulating inflammation in asthma and the redundancy of these processes. Clinical studies also indicate that phenotypes of asthma exist which may have very specific patterns of inflammation that require different treatment approaches. Current studies are investigating novel therapies targeted at the cytokines, chemokines, and inflammatory cells farther upstream in the inflammatory process. For example, drugs designed to inhibit the Th2 inflammatory pathway may cause a broad spectrum of effects such as airway hyperresponsiveness and mucus hypersecretion. ${ }^{54}$ Further research into the mechanisms responsible for the varying asthma phenotypes and appropriately targeted therapy may enable improved control for all manifestations of asthma and prevention of disease progression. In some patients, persistent changes in airway structure occur, including subbasement fibrosis, mucus hypersecretion, injury to epithelial cells, smooth muscle hypertrophy, and angiogenesis.

In summary, asthma is an atopic/allergic disease that involves complex interactions among susceptible genes, immunological factors, infections, neuroendocrine factors, and environmental factors. Asthma is a common, chronic disorder of the airways that involves a complex interaction of airflow obstruction, bronchial hyperresponsiveness, and underlying inflammation. ${ }^{54}$ This interaction can be highly variable among patients and within patients over time. This section presents a definition of asthma, a description of the processes on which that definition is based, the pathophysiology, pathogenesis, and natural history of asthma, with implications in the use of leukotriene receptor antagonist (LTRA) for treatment.

\section{Montelukast as a class of immunomodulant for asthma}

Therapeutic management of asthma exacerbation and maintenance must take into account the complicated airway disease and its diverse pathophysiologic factors. ${ }^{52}$ Since the 1980 s, a new class of montelukasts has been available for the treatment of childhood asthma, and many clinical trials on montelukast have been published.

Montelukast (Singulair ${ }^{\circledR}$, Merck \& Co., Inc., Whitehouse Station, NJ, USA) is a cysteinyl LTRA used for the maintenance treatment of asthma and to relieve symptoms of 
seasonal allergies. Montelukast acts by blocking the action of leukotriene D4 (and secondary ligands, leukotrienes C4 and E4) on the cysteinyl leukotriene receptor CysLT1 in the lungs and bronchial tubes by binding to it. This reduces the bronchoconstriction otherwise caused by the leukotriene and results in less inflammation. Because of its method of operation, it is not useful for the treatment of acute asthmatic attacks. ${ }^{55}$ The cysteinyl leukotrienes C4, D4, and E4 are end products of the arachidonic acid pathway and are potent mediators of antigen-induced contractions of airway smooth muscle. ${ }^{56}$ Montelukast acts by antagonizing these compounds at their receptor, thus protecting against bronchoconstriction. It is the only LTRA currently licensed for use in children with asthma. The medication is available as chewable tablets, tablets, and sprinkle sachet formulation. It is taken once a day, preferably in the evening.

Another LTRA is zafirlukast (Accolate ${ }^{\circledR}$, AstraZeneca plc, London, UK), taken twice daily. Zileuton $\left(Z y f l{ }^{\circledR}\right.$, Cornerstone Therapeutics Inc., Cary NC, USA), a drug used for the treatment of asthma, taken four times per day, blocks leukotriene synthesis by inhibiting 5-lipoxygenase, an enzyme of the eicosanoid synthesis pathway. It is mainly used as a complementary therapy in adults in addition to inhaled corticosteroids (ICSs) if they alone do not bring the desired effect.

There is well-accepted evidence that oral montelukast is an effective initial preventer therapy for children with mild asthma. ${ }^{57,58}$ In addition, it seems to confer additional benefit as an add-on therapy to ICS in those who are inadequately controlled on ICS. ${ }^{59}$ It is also indicated in the prophylaxis of asthma in which the predominant component is exerciseinduced bronchospasm. There is considerable interindividual heterogeneity in the efficacy of montelukast, but as yet, no firm clinical predictors of response have been identified. ${ }^{60}$ Montelukast is generally safe and well tolerated; headache and gastrointestinal symptoms are the most commonly reported side effects. ${ }^{57}$ Other side effects include hypersensitivity reactions, sleep disorders, drowsiness, increased bleeding tendency, hallucination, and possible mood changes and suicidal thoughts. Its use is associated with a higher incidence of Churg-Strauss syndrome (whether or not this drug is "unmasking" subclinical Churg-Strauss is as yet uncertain).

\section{Effectiveness, clinical efficacy, and safety of montelukast in asthma: a literature review}

In this review, we performed an extensive literature search on the clinical efficacy and safety of montelukast. Research reports were retrieved from PubMed and the Cochrane Database for Systematic Reviews for this review. Using the following search terms, we searched PubMed, Clinical Queries for articles: "asthma" AND “montelukast" AND "clinical efficacy", "meta-analysis", OR "safety", OR "adverse effects". We limited our search to include randomized trials, case control studies, and large case series. Limits were also set to include human studies and English language articles only, but with no time limits imposed. Studies were also found by reviewing the reference sections of the retrieved articles found in the Clinical Queries search. Studies on exercise-induced bronchospasm, viral-induced asthma, and smoking-induced asthma were separately searched and identified.

As of December 2013, we retrieved 48 articles from PubMed, Clinical Queries using the keywords "asthma" and "montelukast". All randomized clinical trials (RCTs) and relevant case control studies were included. Review articles that did not provide any information on montelukast efficacy or side effects were excluded. Effectiveness relates to how well a treatment works in the practice of medicine, as opposed to efficacy, which measures how well treatment works in clinical trials or laboratory studies. Studies without evaluation of effectiveness/efficacy, safety, or adverse effects were not appraised in detail.

Among the 48 articles retrieved, only 25 were relevant articles, and 20 more articles (three meta-analyses and reviews and 17 RCTs, marked * in Tables 1 and 2) were retrieved from the reference sections of the 25 articles as well as the authors' own database and separate search. These are summarized as (systematic) reviews and meta-analyses in Table 1 and randomized trials in Table 2. There were 24 reviews and meta-analyses that involved pooling of data and statistical analyses. Relevant case control studies and cohorts are cited but not included in the tables.

Among the (systematic) reviews and meta-analyses, it is generally concluded that LTRAs should be considered when the combination of an ICS plus a long-acting beta 2-agonist (LABA) fails to satisfactorily control symptoms or after a failed trial of a LABA (Table 1). ${ }^{61,62}$ These studies report that LTRA is generally inferior to ICS. One review shows that the risk of asthma exacerbations and hospitalizations is seven times higher in children on montelukast treatment than in those receiving ICSs. ${ }^{63}$ However, LTRAs (montelukast, zafirlukast, and zileuton) may be used in patients with mild persistent asthma as well as in combination with other asthma medications at all levels of disease severity for long-term maintenance of asthma control. ${ }^{64}$ 


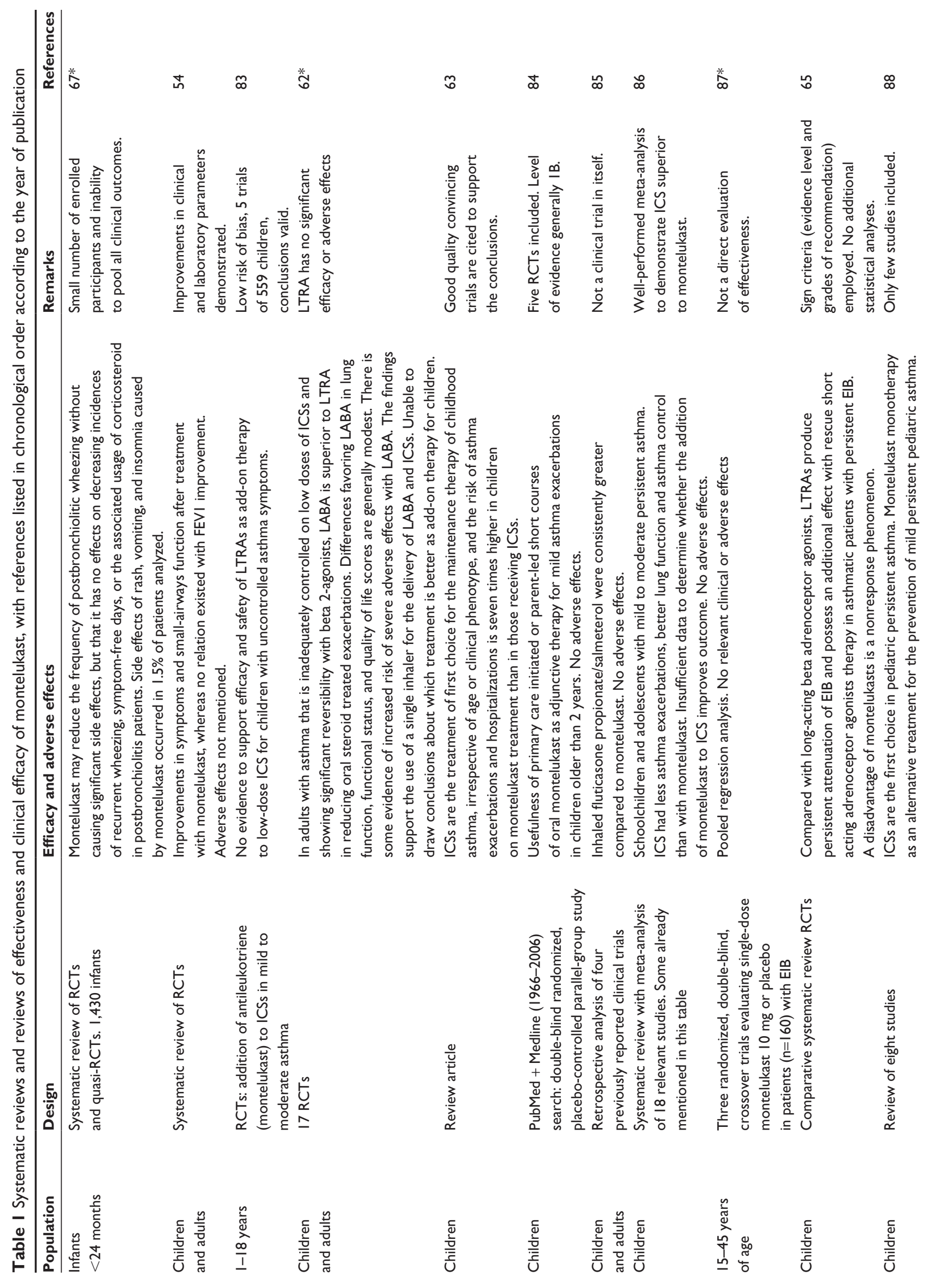




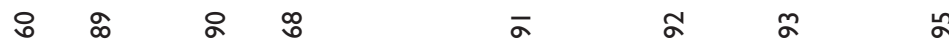
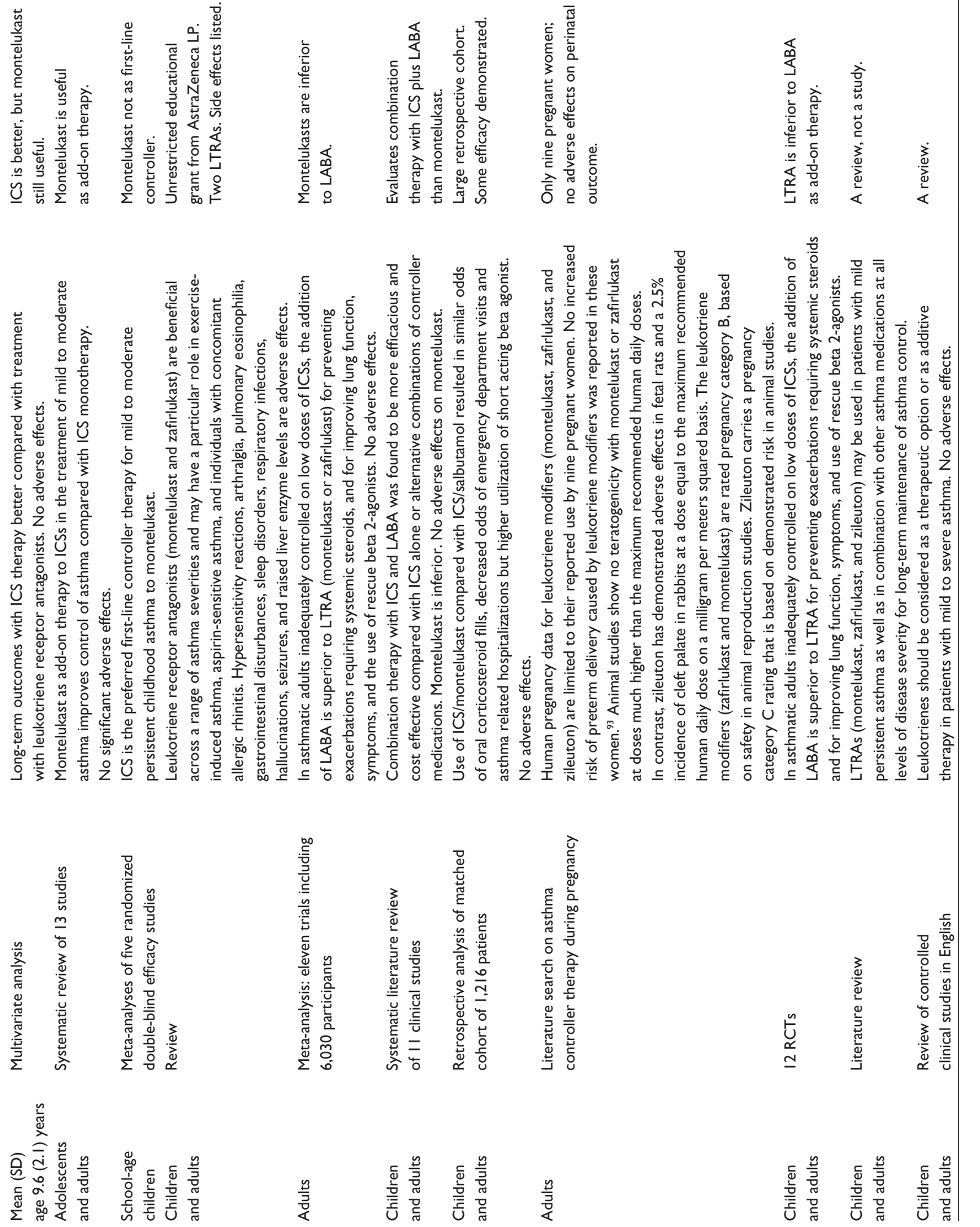

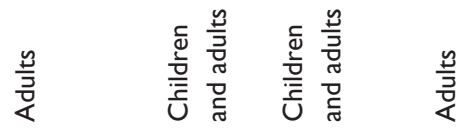

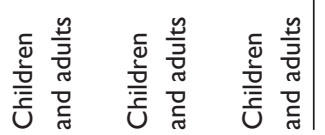




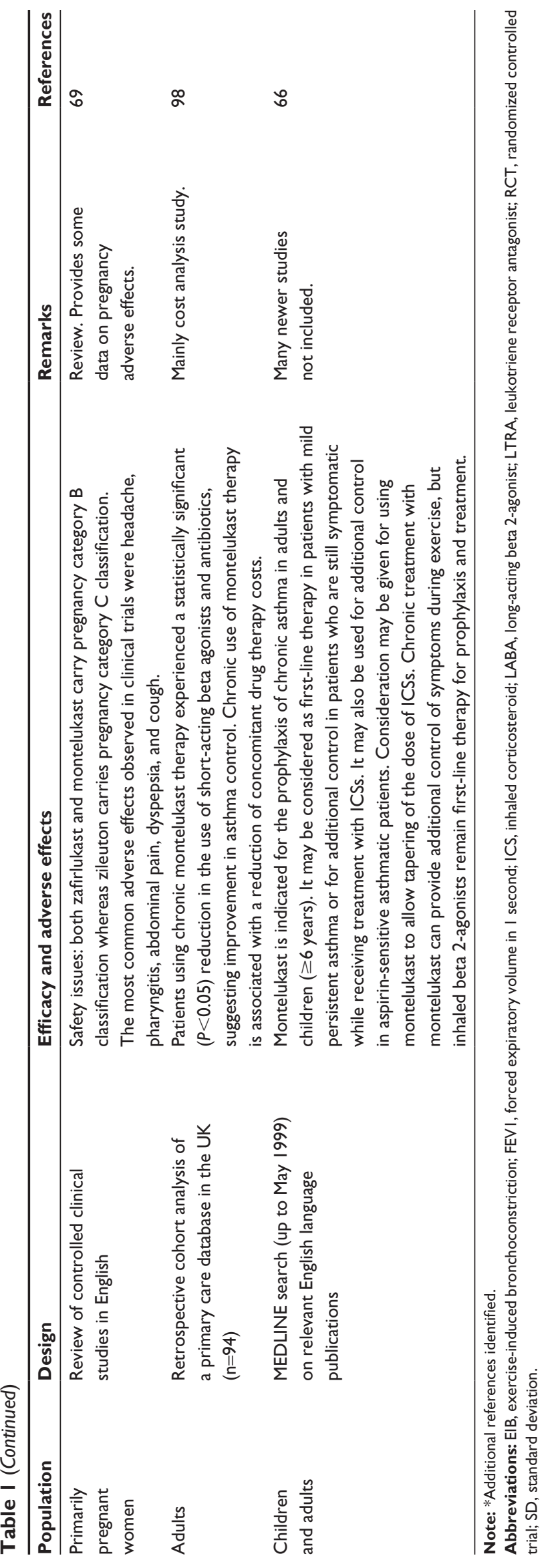

Exercise-induced bronchoconstriction (EIB) was specifically evaluated in two of the studies. In a comparative systematic review of RCTs in children, the authors conclude that compared with LABAs, LTRAs produce persistent attenuation of EIB and possess an additional effect with rescue short-acting adrenoceptor agonists therapy in asthmatic patients with persistent EIB. ${ }^{65}$ Blake concludes that chronic treatment with montelukast can provide additional control of symptoms during exercise, but inhaled beta 2-agonists remain first-line therapy for prophylaxis and treatment. ${ }^{66}$

Postbronchiolitis wheezing is evaluated in a meta-analysis which concludes that montelukast may reduce the frequency of postbronchiolitic wheezing without causing significant side effects but that it has no effects on decreasing incidences of recurrent wheezing, symptom-free days, or the associated usage of corticosteroid in postbronchiolitis infants. ${ }^{67}$

Adverse effects of LTRAs are specifically commented on in two of the earlier studies. One review lists hypersensitivity reactions, arthralgia, pulmonary eosinophilia, gastrointestinal disturbances, sleep disorders, respiratory infections, hallucinations, seizures, and raised liver enzyme levels, ${ }^{68}$ whereas the other lists headache, pharyngitis, abdominal pain, dyspepsia, and cough being the most common adverse effects observed in clinical trials. ${ }^{69}$

Among the RCTs, LTRAs are generally shown to be safe but inferior to ICS (Table 2). The majority of the randomized trials are placebo-controlled and montelukast as addedon trials. Most of these RCTs have relative small patient numbers. Nevertheless, one double-blind, multicenter, multinational study at 93 centers worldwide $(\mathrm{n}=689)$ demonstrates montelukast improves multiple clinical parameters of asthma control without important adverse effects. ${ }^{57}$

Three randomized control trials specifically evaluated EIB. In one RCT, children aged 6 to 18 years with EIB were randomized in a 4-week, placebo-controlled, double-blinded trial with montelukast or ICS (fluticasone propionate [FP]). The efficacy of montelukast for preventing a maximum decrease in forced expiratory volume in 1 second (FEV1) after exercise is significantly higher than that of FP, and the high leukotriene E4/fractional exhaled nitric oxide ratio is associated with a greater response to montelukast than to FP for EIB therapy. ${ }^{70}$ Another randomized, double-blind, placebo-controlled, two-period crossover study evaluated the onset and duration of EIB attenuation in children after a single dose of montelukast and found single-dose montelukast provided rapid and sustained EIB attenuation in children. ${ }^{71}$ Effect of montelukast was also shown to be better than salmeterol added to inhaled fluticasone on EIB in children 


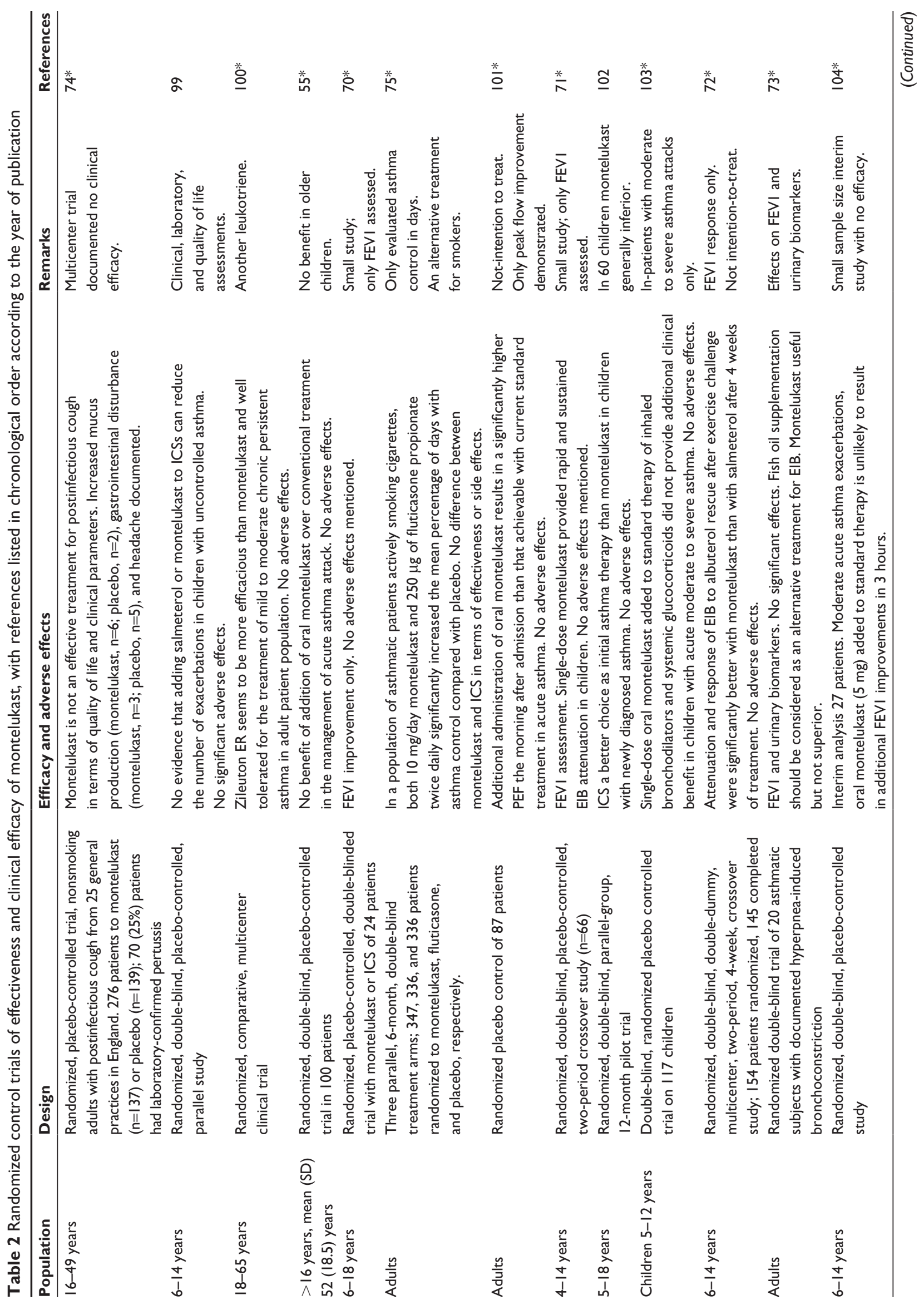




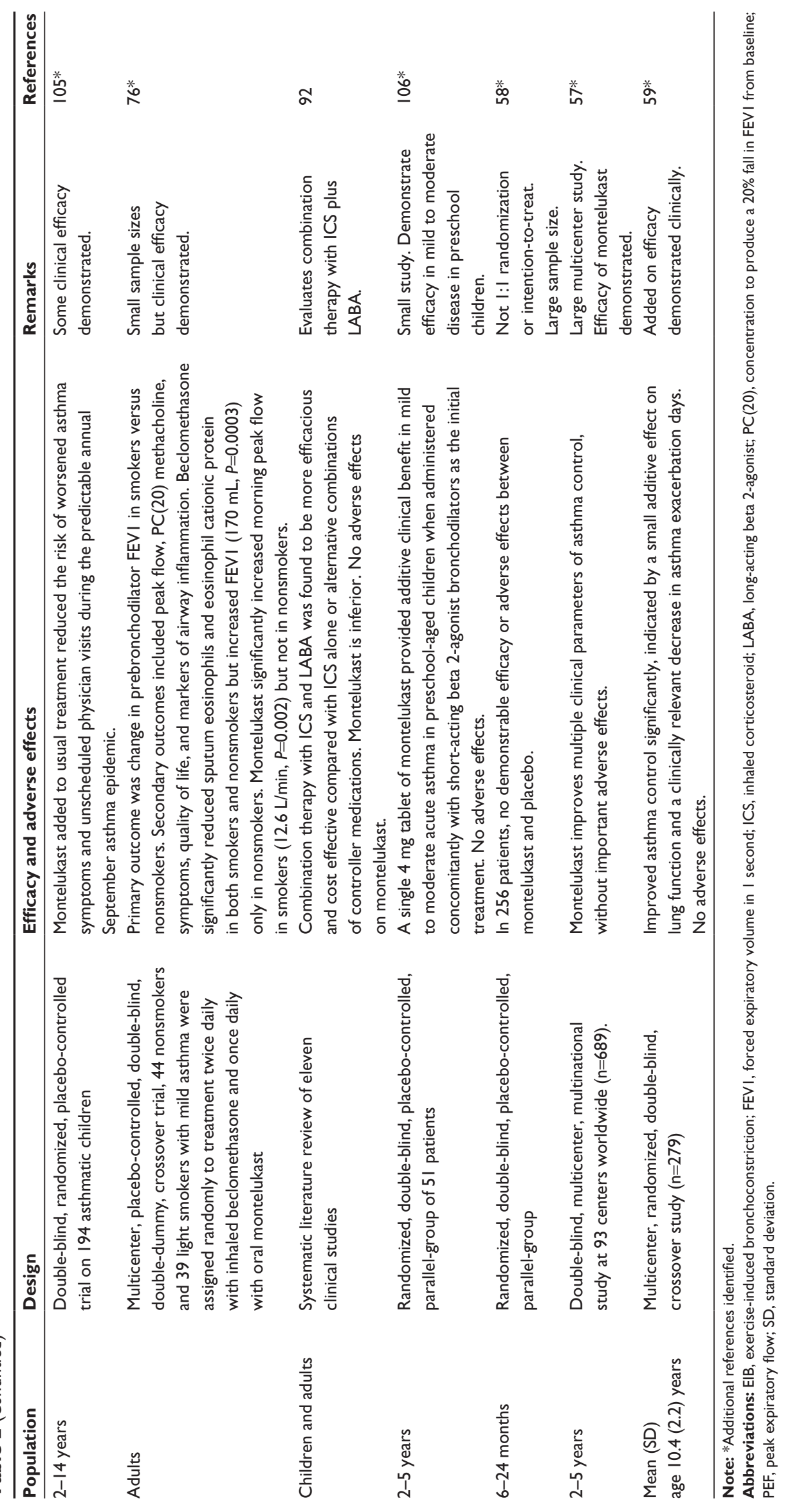


in a randomized, double-blind, double-dummy, multicenter, two-period, 4-week, crossover study. ${ }^{72}$ Also, both fish oil and montelukast have been shown to reduce the severity of EIB, but montelukast is not superior to fish oil. ${ }^{73}$

A randomized, placebo-controlled trial on nonsmoking adults from 25 general practices in England showed montelukast was not an effective treatment for postinfectious cough. ${ }^{74}$ Nevertheless, smoking is a relevant issue in asthma, especially in adult patients. Price et al evaluated $10 \mathrm{mg}$ /day montelukast and $250 \mu \mathrm{g}$ of fluticasone propionate twice daily, each compared with placebo, in patients with self-reported active smoking and asthma. Both $10 \mathrm{mg}$ /day montelukast and $250 \mu \mathrm{g}$ of fluticasone propionate twice daily significantly increased the mean percentage of days with asthma control compared with placebo. ${ }^{75}$ In another multicenter, placebocontrolled, double-blind, double-dummy, crossover trial, 44 nonsmokers and 39 light smokers with mild asthma were assigned randomly to treatment twice daily with inhaled beclomethasone and once daily with oral montelukast. In subjects with mild asthma who smoke, the response to ICSs was attenuated, suggesting that adjustments to standard therapy may be required to attain asthma control. The study demonstrated greater improvement in some outcomes in smokers treated with montelukast. ${ }^{76}$

These systematic reviews and RCTs published between 1999 and 2013 led to the conclusions in most asthma management guidelines that ICS should remain the first-line therapy for persistent asthma in children. LTRAs (primarily montelukast) are not the first choice for persistent severe asthma. ${ }^{3}$ LTRAs should be considered when the combination of an ICS plus a LABA fails to satisfactorily control symptoms or after a failed trial of a long-acting beta 2-agonist. However, several studies suggest that when evaluating outcome parameters other than lung function (in particular exacerbation frequency), LTRAs may have efficacy similar to LABAs. Indeed, many patients using ICSs have relatively normal FEV1, suggesting that underlying inflammation and airway hyperresponsiveness are the driving forces behind continued episodic airflow obstruction and symptoms. The FEV1 response was also documented in a cohort of 22 atopic asthmatic children aged 7 to 16 years with reproducible EIB. A once daily treatment with oral montelukast attenuated the immediate-phase response (FEV1) and abolished the late-phase response induced by means of exercise challenge in asthmatic children. ${ }^{77}$ Disuse of add-on LTRAs (odds ratio: 1.42; 95\% confidence interval: 1.06-1.74) was independently associated with moderate to severe symptoms in adult patients with recurrent exacerbations of asthma, especially in association with recurrent episodes of upper respiratory tract infections (URI). ${ }^{78}$ In these patients, addon therapy with a LTRA would appear to be a reasonable therapeutic option in an attempt to more completely attenuate airway hyperresponsiveness and suppress inflammation. Since the long-term safety of LABAs and their associated risks of increased asthma exacerbations have been highlighted, add-on therapy with a LTRA might even become the preferred therapeutic approach. ${ }^{61,62}$ Patients themselves may also express a desire to avoid LABAs since the US Food and Drug Administration has advised that labeling be produced to outline the "small but significant risk in asthma related deaths" associated with their regular use. Furthermore, it could be argued that patients with persistent asthma and concomitant allergic rhinitis using ICSs alone should preferentially be given an LTRA instead of a LABA. On the other hand, the use of high doses of ICSs in very young children may lead to adverse effects such as adrenal suppression and reduced growth velocity. Nevertheless, in a real-world clinical setting subjects were more adherent to ICS + LABA therapy than ICS + LTRA therapy. ICS + LABA therapy seems to be more effective than ICS + LTRA therapy in the management of asthma, regardless of adherence. ${ }^{79}$ URIs represent the most frequent cause of acute asthma exacerbations. Use of an LTRA for adult asthmatic patients appears to reduce the incidences of URIs alone and acute asthma exacerbations without URI, but it failed to prevent URI-induced acute asthma exacerbations once a URI occurred, unless combined with ICS. ${ }^{80,81}$

The LTRAs generally have low adverse effect profiles, which include hypersensitivity reactions, arthralgia, pulmonary eosinophilia, gastrointestinal disturbances, sleep disorders, respiratory infections, hallucinations, seizures, raised liver enzyme levels, headache, pharyngitis, abdominal pain, dyspepsia, and cough. ${ }^{68,69}$ In particular, a significant increase in alkaline phosphatase level may occur in some children following LTRA. ${ }^{68,82}$ Agitation symptoms may also occur that subside after drug withdrawal. ${ }^{82}$

In conclusion, LTRAs can be used as a monotherapy or as an add-on therapy in addition to ICS. They may be an effective alternative in asthma control and safe even with long-term usage. The advantages of LRTAs include low risks of side effects and rapid onset of action and achievement of peak effect. The fact that medication has to be given orally only once a day and that no inhaler is necessary will help to improve patient satisfaction and compliance, especially in the pediatric age group. Montelukast has a place in the treatment of young children with viral-triggered wheezing diseases, 
exercise-induced asthma, and in children whose parents are steroid-phobic and find ICS unacceptable. The judicious use of montelukast may lead to a reduction in health care visits, a savings in health care dollars, better asthma control, and reduced amount of time off school and from work.

\section{Disclosure}

The authors report no conflicts of interest in this work.

\section{References}

1. Becker A, Lemiere C, Berube D, et al. Summary of recommendations from the Canadian Asthma Consensus guidelines, 2003. CMAJ. 2005;173(6 Suppl):S3-S11.

2. Hon KL, Wang SS, Leung TF. The atopic march: from skin to the airways. Iran J Allergy Asthma Immunol. 2012;11(1):73-77.

3. Cannon E. Aligning patient care and asthma treatment guidelines. Am J Manag Care. 2005;11(Suppl 14):S416-S421; quiz 427.

4. Simpson EL, Hanifin JM. Atopic dermatitis. J Am Acad Dermatol. 2005;53(1):115-128.

5. Leung AK, Hon KL, Robson WL. Atopic dermatitis. Adv Pediatr. 2007;54:241-273.

6. Leung R, Wong G, Lau J, et al. Prevalence of asthma and allergy in Hong Kong schoolchildren: an ISAAC study. Eur Respir J. 1997;10(2): 354-360.

7. Leung DY, Nicklas RA, Li JT, et al. Disease management of atopic dermatitis: an updated practice parameter. Joint Task Force on Practice Parameters. Ann Allergy Asthma Immunol. 2004;93(3 Suppl 2): S1-S21.

8. Simpson EL. Atopic dermatitis: a review of topical treatment options. Curr Med Res Opin. 2010;26(3):633-640.

9. Shaw TE, Currie GP, Koudelka CW, Simpson EL. Eczema prevalence in the United States: data from the 2003 National Survey of Children's Health. J Invest Dermatol. 2011;131(1):67-73.

10. Leung AK, Barber KA. Managing childhood atopic dermatitis. $A d v$ Ther. 2003;20(3):129-137.

11. Li F, Zhou Y, Li S, et al. Prevalence and risk factors of childhood allergic diseases in eight metropolitan cities in China: a multicenter study. BMC Public Health. 2011;11:437.

12. Hon KL, Nelson EA. Gender disparity in paediatric hospital admissions. Ann Acad Med Singapore. 2006;35(12):882-888.

13. Bufford JD, Gern JE. The hygiene hypothesis revisited. Immunol Allergy Clin North Am. 2005;25(2):247-262, v.

14. Flohr C, Yeo L. Atopic dermatitis and the hygiene hypothesis revisited. Curr Probl Dermatol. 2011;41:1-34.

15. Patterson R, Walker CL, Greenberger PA, Sheridan EP. Prednisonephobia. Allergy Proc. 1989;10(6):423-428.

16. Tuft L. "Steroid-phobia" in asthma management. Ann Allergy. 1979;42(3):152-159.

17. Zedan MM, Ezz El Regal M, A Osman E, E Fouda A. Steroid phobia among parents of asthmatic children: myths and truth. Iran J Allergy Asthma Immunol. 2010;9(3):163-168.

18. Skoner JD, Schaffner TJ, Schad CA, Kwon AY, Skoner DP. Addressing steroid phobia: improving the risk-benefit ratio with new agents. Allergy Asthma Proc. 2008;29(4):358-364.

19. Hon KL, Tang WS, Leung TF, Cheung KL, Ng PC. Outcome of children with life-threatening asthma necessitating pediatric intensive care. Ital J Pediatr. 2010;36:47.

20. Hon KL, Kam WY, Leung TF, et al. Steroid fears in children with eczema. Acta Paediatr. 2006;95(11):1451-1455.

21. Chen HY, Lin YH, Thien PF, et al. Identifying core herbal treatments for children with asthma: implication from a chinese herbal medicine database in taiwan. Evid Based Complement Alternat Med. 2013;2013: 125943.
22. Hon KL, Leung TF, Ma KC, Wong Y, Fok TF. Brief case series: montelukast, at doses recommended for asthma treatment, reduces disease severity and increases soluble CD14 in children with atopic dermatitis. J Dermatolog Treat. 2005;16(1):15-18.

23. Hon KLE, Leung TF. Killing many birds with one stone. HKJ Paediatr. 2008;13:135-138.

24. Chu HW, Martin RJ. Are eosinophils still important in asthma? Clin Exp Allergy. 2001;31(4):525-528.

25. Sampson AP. The role of eosinophils and neutrophils in inflammation. Clin Exp Allergy. 2000;30(Suppl 1):22-27.

26. Williams TJ. The eosinophil enigma. J Clin Invest. 2004;113(4): 507-509.

27. Brightling CE, Bradding P, Symon FA, Holgate ST, Wardlaw AJ, Pavord ID. Mast-cell infiltration of airway smooth muscle in asthma. $N$ Engl J Med. 2002;346(22):1699-1705.

28. Fahy JV, Kim KW, Liu J, Boushey HA. Prominent neutrophilic inflammation in sputum from subjects with asthma exacerbation. $J$ Allergy Clin Immunol. 1995;95(4):843-852.

29. Jatakanon A, Uasuf C, Maziak W, Lim S, Chung KF, Barnes PJ. Neutrophilic inflammation in severe persistent asthma. Am J Respir Crit Care Med. 1999;160(5 Pt 1):1532-1539.

30. Wenzel SE, Szefler SJ, Leung DY, Sloan SI, Rex MD, Martin RJ. Bronchoscopic evaluation of severe asthma. Persistent inflammation associated with high dose glucocorticoids. Am J Respir Crit Care Med. 1997;156(3 Pt 1):737-743.

31. Wenzel SE. Asthma: defining of the persistent adult phenotypes. Lancet. 2006;368(9537):804-813.

32. Peters-Golden M. The alveolar macrophage: the forgotten cell in asthma. Am J Respir Cell Mol Biol. 2004;31(1):3-7.

33. Kuipers H, Lambrecht BN. The interplay of dendritic cells, Th2 cells and regulatory T cells in asthma. Curr Opin Immunol. 2004;16(6): 702-708.

34. Polito AJ, Proud D. Epithelia cells as regulators of airway inflammation. J Allergy Clin Immunol. 1998;102(5):714-718.

35. Cohn L, Elias JA, Chupp GL. Asthma: mechanisms of disease persistence and progression. Annu Rev Immunol. 2004;22:789-815.

36. Akbari O, Faul JL, Hoyte EG, et al. CD4+ invariant T-cell-receptor+ natural killer T cells in bronchial asthma. N Engl J Med. 2006;354(11): $1117-1129$.

37. Larché M, Robinson DS, Kay AB. The role of T lymphocytes in the pathogenesis of asthma. J Allergy Clin Immunol. 2003;111(3):450-463; quiz 464.

38. Barnes PJ. Cytokine modulators as novel therapies for asthma. Annu Rev Pharmacol Toxicol. 2002;42:81-98.

39. Zimmermann N, Hershey GK, Foster PS, Rothenberg ME. Chemokines in asthma: cooperative interaction between chemokines and IL-13. J Allergy Clin Immunol. 2003;111(2):227-242; quiz 243.

40. Leung TF, Wong CK, Chan IH, Ip WK, Lam CW, Wong GW. Plasma concentration of thymus and activation-regulated chemokine is elevated in childhood asthma. J Allergy Clin Immunol. 2002;110(3): 404-409.

41. Boyce JA. Mast cells: beyond IgE. J Allergy Clin Immunol. 2003;111(1): 24-32; quiz 33.

42. Galli SJ, Kalesnikoff J, Grimbaldeston MA, Piliponsky AM, Williams CM, Tsai M. Mast cells as "tunable" effector and immunoregulatory cells: recent advances. Annu Rev Immunol. 2005;23: 749-786.

43. Robinson DS. The role of the mast cell in asthma: induction of airway hyperresponsiveness by interaction with smooth muscle? J Allergy Clin Immunol. 2004;114(1):58-65.

44. Busse WW. The role of leukotrienes in asthma and allergic rhinitis. Clin Exp Allergy. 1996;26(8):868-879.

45. Leff AR. Regulation of leukotrienes in the management of asthma: biology and clinical therapy. Annu Rev Med. 2001;52:1-14.

46. Gelfand EW, Dakhama A. CD8+ T lymphocytes and leukotriene B4: novel interactions in the persistence and progression of asthma. J Allergy Clin Immunol. 2006;117(3):577-582. 
47. Deykin A, Massaro AF, Drazen JM, Israel E. Exhaled nitric oxide as a diagnostic test for asthma: online versus offline techniques and effect of flow rate. Am J Respir Crit Care Med. 2002;165(12):1597-1601.

48. Strunk RC, Szefler SJ, Phillips BR, et al; Childhood Asthma Research and Education Network of the National Heart, Lung, and Blood Institute. Relationship of exhaled nitric oxide to clinical and inflammatory markers of persistent asthma in children. J Allergy Clin Immunol. 2003;112(5):883-892.

49. Green RH, Brightling CE, McKenna S, et al. Asthma exacerbations and sputum eosinophil counts: a randomised controlled trial. Lancet. 2002;360(9347):1715-1721.

50. Hon KL, Leung TF, Kam WY, et al. Exhaled nitric oxide levels are not correlated with eczema severity in Chinese children with atopic dermatitis. J Asthma. 2006;43(6):417-419.

51. Sporik R, Ingram JM, Price W, Sussman JH, Honsinger RW, Platts-Mills TA. Association of asthma with serum IgE and skin test reactivity to allergens among children living at high altitude. Tickling the dragon's breath. Am J Respir Crit Care Med. 1995;151(5) 1388-1392.

52. Busse W, Corren J, Lanier BQ, et al. Omalizumab, anti-IgE recombinant humanized monoclonal antibody, for the treatment of severe allergic asthma. J Allergy Clin Immunol. 2001;108(2):184-190.

53. Holgate S, Casale T, Wenzel S, Bousquet J, Deniz Y, Reisner C. The anti-inflammatory effects of omalizumab confirm the central role of IgE in allergic inflammation. J Allergy Clin Immunol. 2005;115(3): 459-465.

54. van der Wiel E, ten Hacken NH, Postma DS, van den Berge M. Smallairways dysfunction associates with respiratory symptoms and clinical features of asthma: a systematic review. J Allergy Clin Immunol. 2013;131(3):646-657.

55. Zubairi AB, Salahuddin N, Khawaja A, et al. A randomized, doubleblind, placebo-controlled trial of oral montelukast in acute asthma exacerbation. BMC Pulm Med. 2013;13:20.

56. Dahlén SE. Treatment of asthma with antileukotrienes: first line or last resort therapy? Eur J Pharmacol. 2006;533(1-3):40-56.

57. Knorr B, Franchi LM, Bisgaard H, et al. Montelukast, a leukotriene receptor antagonist, for the treatment of persistent asthma in children aged 2 to 5 years. Pediatrics. 2001;108(3):E48.

58. van Adelsberg J, Moy J, Wei LX, Tozzi CA, Knorr B, Reiss TF. Safety, tolerability, and exploratory efficacy of montelukast in 6- to 24-month-old patients with asthma. Curr Med Res Opin. 2005;21(6): 971-979.

59. Simons FE, Villa JR, Lee BW, et al. Montelukast added to budesonide in children with persistent asthma: a randomized, double-blind, crossover study. J Pediatr. 2001;138(5):694-698.

60. Knuffman JE, Sorkness CA, Lemanske RF Jr, et al; Childhood Asthma Research and Education Network of the National Heart, Lung, and Blood Institute. Phenotypic predictors of long-term response to inhaled corticosteroid and leukotriene modifier therapies in pediatric asthma J Allergy Clin Immunol. 2009;123(2):411-416.

61. Ducharme FM, Ni Chroinin M, Greenstone I, Lasserson TJ. Addition of long-acting beta2-agonists to inhaled steroids versus higher dose inhaled steroids in adults and children with persistent asthma. Cochrane Database Syst Rev. 2010;4:CD005533.

62. Ducharme FM, Lasserson TJ, Cates CJ. Addition to inhaled corticosteroids of long-acting beta2-agonists versus anti-leukotrienes for chronic asthma. Cochrane Database Syst Rev. 2011;5:CD003137.

63. Brand PL. Inhaled corticosteroids should be the first line of treatment for children with asthma. Paediatr Respir Rev. 2011;12(4):245-249.

64. Nathan RA, Kemp JP; Antileukotriene Working Group. Efficacy of antileukotriene agents in asthma management. Ann Allergy Asthma Immunol. 2001;86(6 Suppl 1):9-17.

65. Grzelewski T, Stelmach I. Exercise-induced bronchoconstriction in asthmatic children: a comparative systematic review of the available treatment options. Drugs. 2009;69(12):1533-1553.

66. Blake KV. Montelukast: data from clinical trials in the management of asthma. Ann Pharmacother. 1999;33(12):1299-1314.
67. Peng WS, Chen X, Yang XY, Liu EM. Systematic review of montelukast's efficacy for preventing post-bronchiolitis wheezing. Pediatr Allergy Immunol. 2014;25(2):143-150.

68. Currie GP, McLaughlin K. The expanding role of leukotriene receptor antagonists in chronic asthma. Ann Allergy Asthma Immunol. 2006;97(6):731-741, quiz 741.

69. Spector SL; Antileukotriene Working Group. Safety of antileukotriene agents in asthma management. Ann Allergy Asthma Immunol. 2001; 86(6 Suppl 1):18-23.

70. Baek HS, Cho J, Kim JH, Oh JW, Lee HB. Ratio of leukotriene e(4) to exhaled nitric oxide and the therapeutic response in children with exercise-induced bronchoconstriction. Allergy Asthma Immunol Res. 2013;5(1):26-33.

71. Wasfi YS, Kemp JP, Villarán C, et al. Onset and duration of attenuation of exercise-induced bronchoconstriction in children by single-dose of montelukast. Allergy Asthma Proc. 2011;32(6):453-459.

72. Fogel RB, Rosario N, Aristizabal G, et al. Effect of montelukast or salmeterol added to inhaled fluticasone on exercise-induced bronchoconstriction in children. Ann Allergy Asthma Immunol. 2010;104(6): 511-517.

73. Tecklenburg-Lund S, Mickleborough TD, Turner LA, Fly AD, Stager JM, Montgomery GS. Randomized controlled trial of fish oil and montelukast and their combination on airway inflammation and hyperpnea-induced bronchoconstriction. PLoS One. 2010;5(10): e13487.

74. Wang K, Birring SS, Taylor K, et al. Montelukast for postinfectious cough in adults: a double-blind randomised placebo-controlled trial. Lancet Respir Med. 2014;2(1):35-43.

75. Price D, Popov TA, Bjermer L, et al. Effect of montelukast for treatment of asthma in cigarette smokers. J Allergy Clin Immunol. 2013;131(3):763-771.

76. Lazarus SC, Chinchilli VM, Rollings NJ, et al; National Heart Lung and Blood Institute's Asthma Clinical Research Network. Smoking affects response to inhaled corticosteroids or leukotriene receptor antagonists in asthma. Am J Respir Crit Care Med. 2007;175(8): 783-790.

77. Melo RE, Solé D, Naspitz CK. Exercise-induced bronchoconstriction in children: montelukast attenuates the immediate-phase and late-phase responses. J Allergy Clin Immunol. 2003;111(2):301-307.

78. Tomita K, Sano H, Iwanaga T, et al. Association between episodes of upper respiratory infection and exacerbations in adult patients with asthma. J Asthma. 2012;49(3):253-259.

79. Sadatsafavi M, Lynd L, Marra C, Bedouch P, Fitzgerald M. Comparative outcomes of leukotriene receptor antagonists and long-acting $\beta$-agonists as add-on therapy in asthmatic patients: a population-based study. J Allergy Clin Immunol. 2013;132(1): 63-69

80. Matsuse H, Fukahori S, Tsuchida T, et al. Effects of a short course of pranlukast combined with systemic corticosteroid on acute asthma exacerbation induced by upper respiratory tract infection. J Asthma. 2012;49(6):637-641.

81. Matsuse H, Tsuchida T, Fukahori S, et al. Retrospective cohort study of leukotriene receptor antagonist therapy for preventing upper respiratory infection-induced acute asthma exacerbations. Allergy Rhinol (Providence). 2013;4(3):e127-e131.

82. Mustafa FH, Salem NA, Daham M. Therapeutic and some biochemical studies of montelukast and ketotifen in children with mild asthma. Global J Med Res. 2012; 12Ver 1.0.

83. Chauhan BF, Ben Salah R, Ducharme FM. Addition of anti-leukotriene agents to inhaled corticosteroids in children with persistent asthma. Cochrane Database Syst Rev. 2013;10:CD009585.

84. Capsomidis A, Tighe M. Archimedes. Question 2. Is oral montelukast beneficial in treating acute asthma exacerbations in children? Arch Dis Child. 2010;95(11):948-950.

85. Camargo CA, Boulet LP, Sutherland ER, et al. Body mass index and response to asthma therapy: fluticasone propionate/salmeterol versus montelukast. J Asthma. 2010;47(1):76-82. 
86. Castro-Rodriguez JA, Rodrigo GJ. The role of inhaled corticosteroids and montelukast in children with mild-moderate asthma: results of a systematic review with meta-analysis. Arch Dis Child. 2010;95(5): 365-370.

87. Philip G, Swern AS, Smugar SS, Pearlman DS. Baseline predictors of placebo response in exercise-induced bronchoconstriction (EIB): pooled regression analysis $>$ from three studies of montelukast in EIB. J Asthma. 2010;47(8):935-941.

88. Miceli Sopo S, Onesimo R, Radzik D, Scala G, Cardinale F. Montelukast versus inhaled corticosteroids as monotherapy for prevention of asthma: which one is best? Allergol Immunopathol (Madr). 2009; 37(1):26-30.

89. Joos S, Miksch A, Szecsenyi J, et al. Montelukast as add-on therapy to inhaled corticosteroids in the treatment of mild to moderate asthma: a systematic review. Thorax. 2008;63(5):453-462.

90. Jartti T. Inhaled corticosteroids or montelukast as the preferred primary long-term treatment for pediatric asthma? Eur J Pediatr. 2008;167(7):731-736.

91. Ducharme FM, Lasserson TJ, Cates CJ. Long-acting beta2-agonists versus anti-leukotrienes as add-on therapy to inhaled corticosteroids for chronic asthma. Cochrane Database Syst Rev. 2006;4:CD003137.

92. Akazawa M, Stempel DA. Single-inhaler combination therapy for asthma: a review of cost effectiveness. Pharmacoeconomics. 2006; 24(10):971-988

93. Allen-Ramey FC, Bukstein D, Luskin A, Sajjan SG, Markson LE. Administrative claims analysis of asthma-related health care utilization for patients who received inhaled corticosteroids with either montelukast or salmeterol as combination therapy. J Manag Care Pharm. 2006; 12(4):310-321.

94. Bracken MB, Triche EW, Belanger K, Saftlas A, Beckett WS, Leaderer BP. Asthma symptoms, severity, and drug therapy: a prospective study of effects on 2205 pregnancies. Obstet Gynecol. 2003;102(4): 739-752.

95. Gluck JC, Gluck PA. Asthma controller therapy during pregnancy. Am J Obstet Gynecol. 2005;192(2):369-380.

96. Ram FS, Cates CJ, Ducharme FM. Long-acting beta2-agonists versus anti-leukotrienes as add-on therapy to inhaled corticosteroids for chronic asthma. Cochrane Database Syst Rev. 2005;1:CD003137.
97. Korenblat PE; Antileukotriene Working Group. The role of antileukotrienes in the treatment of asthma. Ann Allergy Asthma Immunol. 2001;86(6 Suppl 1):31-39.

98. Price DB, Ben-Joseph RH, Zhang Q. Changes in asthma drug therapy costs for patients receiving chronic montelukast therapy in the UK. Respir Med. 2001;95(1):83-89.

99. Lenney W, McKay AJ, Tudur Smith C, Williamson PR, James M, Price D; MASCOT Study Group. Management of Asthma in School age Children On Therapy (MASCOT): a randomised, double-blind, placebo-controlled, parallel study of efficacy and safety. Health Technol Assess. 2013;17(4):1-218.

100. Kubavat AH, Khippal N, Tak S, et al. A randomized, comparative, multicentric clinical trial to assess the efficacy and safety of zileuton extended-release tablets with montelukast sodium tablets in patients suffering from chronic persistent asthma. Am J Ther. 2013;20(2): 154-162.

101. Ramsay CF, Pearson D, Mildenhall S, Wilson AM. Oral montelukast in acute asthma exacerbations: a randomised, double-blind, placebocontrolled trial. Thorax. 2011;66(1):7-11.

102. Olszowiec-Chlebna M, Majak P, Brzozowska A, BobrowskaKorzeniowska M, Jerzynska J, Stelmach I. Effect of inhaled steroid and montelukast on clinical symptoms in children with newly diagnosed asthma: a pilot study. Pediatr Allergy Immunol. 2010;21(4 Pt 2): e687-e690.

103. Todi VK, Lodha R, Kabra SK. Effect of addition of single dose of oral montelukast to standard treatment in acute moderate to severe asthma in children between 5 and 15 years of age: a randomised, double-blind, placebo controlled trial. Arch Dis Child. 2010;95(7):540-543.

104. Nelson KA, Smith SR, Trinkaus K, Jaffe DM. Pilot study of oral montelukast added to standard therapy for acute asthma exacerbations in children aged 6 to 14 years. Pediatr Emerg Care. 2008;24(1):21-27.

105. Johnston NW, Mandhane PJ, Dai J, et al. Attenuation of the September epidemic of asthma exacerbations in children: a randomized, controlled trial of montelukast added to usual therapy. Pediatrics. 2007;120(3):e702-e712.

106. Harmanci K, Bakirtas A, Turktas I, Degim T. Oral montelukast treatment of preschool-aged children with acute asthma. Ann Allergy Asthma Immunol. 2006;96(5):731-735.
Drug Design, Development and Therapy

\section{Publish your work in this journal}

Drug Design, Development and Therapy is an international, peerreviewed open-access journal that spans the spectrum of drug design and development through to clinical applications. Clinical outcomes, patient safety, and programs for the development and effective, safe, and sustained use of medicines are a feature of the journal, which

\section{Dovepress}

has also been accepted for indexing on PubMed Central. The manuscript management system is completely online and includes a very quick and fair peer-review system, which is all easy to use. Visit http://www.dovepress.com/testimonials.php to read real quotes from published authors. 